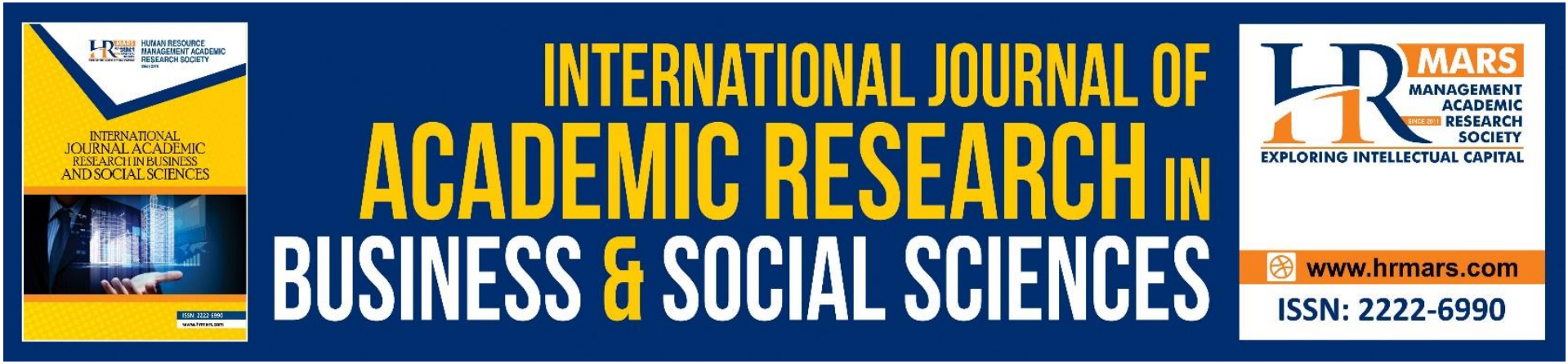

\title{
A Syntactical Analysis of Fresh Graduates' Job Interview Responses
}

Isai Amutan Krishnan \& Mahendran Maniam

To Link this Article: http://dx.doi.org/10.6007/IJARBSS/v11-i10/11448

DOI:10.6007/IJARBSS/v11-i10/11448

Received: 11 August 2021, Revised: 14 September 2021, Accepted: 01 October 2021

Published Online: 24 October 2021

In-Text Citation: (Krishnan \& Maniam, 2021)

To Cite this Article: Krishnan, I. A., \& Maniam, M. (2021). A Syntactical Analysis of Fresh Graduates' Job Interview Responses. International Journal of Academic Research in Business and Social Sciences, 11(10), 761-779.

Copyright: (c) 2021 The Author(s)

Published by Human Resource Management Academic Research Society (www.hrmars.com)

This article is published under the Creative Commons Attribution (CC BY 4.0) license. Anyone may reproduce, distribute, translate and create derivative works of this article (for both commercial and non-commercial purposes), subject to full attribution to the original publication and authors. The full terms of this license may be seen at: http://creativecommons.org/licences/by/4.0/legalcode

Vol. 11, No. 10, 2021, Pg. $761-779$

http://hrmars.com/index.php/pages/detail/IJARBSS

JOURNAL HOMEPAGE

Full Terms \& Conditions of access and use can be found at http://hrmars.com/index.php/pages/detail/publication-ethics 


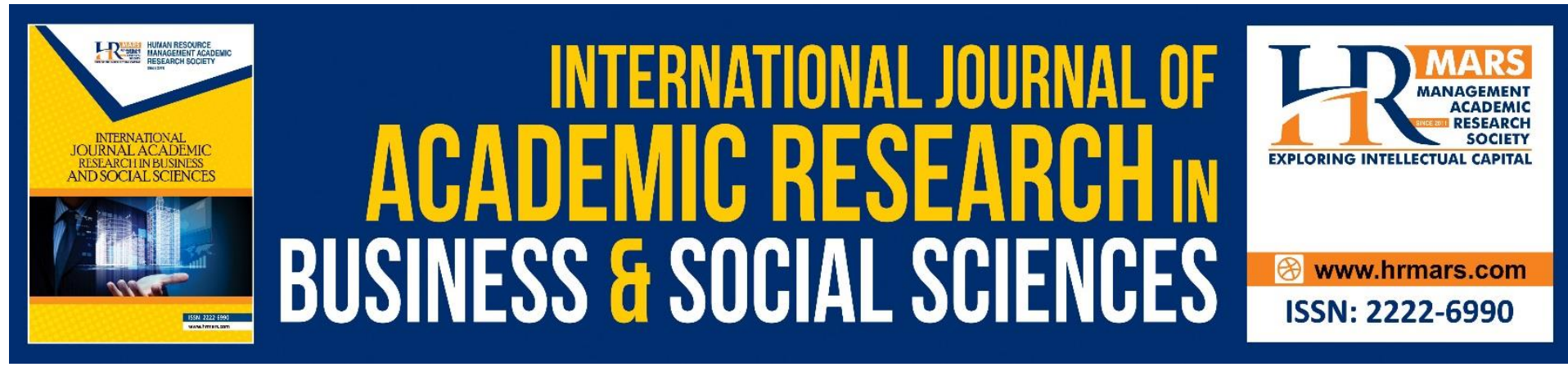

\title{
A Syntactical Analysis of Fresh Graduates' Job Interview Responses
}

\author{
Isai Amutan Krishnan \& Mahendran Maniam \\ Faculty of Languages and Communication, Universiti Pendidikan Sultan Idris, \\ Tanjong Malim, Perak \\ Email: mahendran@fbk.upsi.edu.my
}

\begin{abstract}
The purpose of this paper was to investigate (a) the English language proficiency concerning sentence structure in fresh graduates, and (b) hiring managers' perceptions of the importance of English proficiency in the 21st century workplace. There were forty-five candidates and twenty- five hiring managers from local and foreign instituitions who participated in the study. The data were analysed qualitatively using a sentence structure framework: simple, compound, complex, and compound-complex. The findings revealed that most candidates used simple sentences and were unable to express their complete thoughts due to their lack in English language proficiency. The findings further revealed that hiring managers were willing to consider employing candidates who had good proficiency by expressing their complete thoughts in job interviews. This study has confirmed the need for fresh graduates and undergraduates to know the importance of sentence structures as an important benchmark to show one's proficiency in job interviews.
\end{abstract}

Keywords: Sentence Structures, Job Interviews, Fresh Graduates, Workplace, Malaysia.

\section{Introduction}

In accordance with $21^{\text {st }}$ century workplace goals, Industry 4.0 (IR 4.0), "smart factory" was introduced by Kagermann et al $(2013$, p.24) in Germany. Smart factory focuses on cyberphysical systems to communicate and cooperate with people via cloud computing and crossorganisation communications. Peck (2018) has noted that Malaysian graduates' ability to succeed in embracing IR 4.0 is dependent on their ability to enhance their English proficiency (hereafter proficiency). In line with Peck, Chiristina (2018; Bhattacharyya (2018) have noted that language proficiency is important in gaining the skills required for effective interactions in the workplace.

According to the Malaysia National Graduate Employability Blueprint (2015-2025) (Ministry of Higher Education Malaysia, 2016) and Singh (2018), graduates need to understand the English language and be able to interact by uttering proper sentence structures. Further, in accordance with Singh, and based on employers' perceptions, it was noted that most fresh graduates were unable to speak comprehensively due to a lack of proficiency (Ujang, 2019). Likewise, Abu Bakar (2020) also reported that many graduates 
feared being criticised for their poor proficiency as it was one of the main barriers in getting a job.

This paper aimed to investigate the English proficiency of fresh graduates through their sentence structures, and also examined the perceptions of hiring managers regarding the importance of proficiency among graduates entering the $21^{\text {st }}$ century workplace.

\section{Literature Review}

\section{The Opinions of Linguists on the Role of Syntax in Sentence Structures for Effective Interactions}

Chomsky (1965) stated that syntax is associated with words and phrases. Radford (2009) has noted that syntax is a combination of subject, verb, object, independent and dependent clauses in forming sentence structures with lengthy utterances either in spoken or written forms, based on grammatical rules. Chomsky (1965); Radford (2009) noted that sentence structures consisted of simple, compound, complex and compound-complex sentences.

In agreement with Radford (2009); Raja (2016); Sa'adiyah Sy and Reztia (2019) noted that sentence structures are essential in both speaking and writing. It is also known that a group of sentences consists of grammar elements such as subordinates, objects and modifiers, coordinating conjunctions, dependent clauses and independent clauses to express a complete statement, idea, or thought. It is the basic unit of spoken and written forms because it is the entity in interactions. Further, Radford (2009) noted that if a sentence or utterance has a poor combination of sentence structures, then, understanding becomes difficult (Radford, 2009).

In addition, Halliday (1988, p.79) elaborated that "the spoken language is also, equally ordered and well-constructed as the written form. It has to be similar because both forms are expressions of the same arrangement". Halliday $(2014$, p.215) further noted that the use of various types of sentence structures could make a "prodigious impact and portray a speaker's proficiency". Similarly, Hart et al. (2010, p.21) noted that uttering multiple sentences show one's "promising utterances".

Carter and McCarthy $(1995 ; 2006)$ have claimed that written and spoken languages are the same. Scott and Windsor (2000) found that the use of compound-complex sentences gives a large impact either in spoken or written languages and it should be grammatically correct to represent one's proficiency. Likewise Chomsky (1965); Canale and Swain (1980; 1983); Cleland and Pickering (2006); Koopman et al (2003) have noted that syntactical analysis of sentence structures is one of the important elements in the English language, in spoken and written forms, that determines one's proficiency. Linguists have established that sentence structures play an essential role in spoken and written forms to determine one's proficiency to express longer utterances or complete thoughts in any context of interactions.

\section{Importance of Self-Introduction Question in Job Interviews}

According to Hunting (2019), a self-introduction question is one of the essential questions to commence an interview where candidates show their ability to approach newcomers with confidence. The self-introductory question entails a person's character, name, and academic qualifications and should also focus on the important areas of one's experience that will assist one to be outstanding in job interviews.

Similarly, Murchison (2017) noted that introducing oneself is fundamentally talking about one's personal history including one's strong points and limitations. In line with 
Murchison (2017); Matthew and Nanette (2007); Hansen (2010) have noted that the selfintroduction question can be covered in 30 seconds by candidates, stating who they are, simple educational backgrounds, key accomplishments and their reasons for looking for a job.

\section{Grammatical Competence}

Chomsky (1965); Ohno (2011); Canale and Swain (1980; 1983) have explained that grammatical competence is an essential factor in any communicative event that targets equipping learners or speakers with the capability to articulate correctly.

In the present study, besides the framework of Canale and Swain's (1980; 1983), the framework of grammar competence-sentence structures is applied to provide a comprehensive knowledge of interaction in job interviews. At the same time Radford's (2009) framework on sentence structures is merged with Canale and Swain's $(1980 ; 1983)$ framework. This is because Radford's (2009) definition is more appropriate as per the objective of the study. Similarly, Bachman and Palmer (1996; 2010) noted that by incorporating multiple sentence structures into spoken and written forms, a logical relationship may be created between two or more sentences in communications that demonstrate a speaker's or a writers' proficiency. The definition of sentence structures is provided in Table 1.

\section{(Insert Table 1)}

Table 1 shows that sentence structures consist of simple, compound, complex and compound-complex. Radford (2009) explained that it is important to vary your sentence structures. Therefore, spoken and written words would not be the same, when sentences are combined for different effects, and to emphasize ideas. Radford (2009) also noted that the use of simple and compound sentences are not grammatically wrong in the spoken form. However, any speaker who produces such sentences shows his/her lack of proficiency in professional and social contexts. Uttering a combination of sentence structures varying from compound to complex, and compound-complex shows that the speakers possess a higher degree of syntactical language complexity in expressing their complex ideas. In other words, "several ideas are expressed in a single sentence to express complex thoughts" (Radford, 1990; 1997, p. 390).

\section{Past Studies}

It must be noted that a number of studies have examined communicative competence. Previous studies by Hymes (1972), Wiemann (1977), and Morreale et al. (2007) have found that language plays an important role in communicative competence in social and professional interactions. Alias et al. (2013) reported that most of the graduates in their study had poor communication competence which hindered them in getting jobs. Further, LaSalle (2014) revealed that students were not able to utter suitable words and had incomplete utterances in spoken and written forms. Similarly in another study, Bhattacharyya (2018) discovered that language competence was essential in the workplace for achieving IR 4.0.

Various studies (Chomsky, 2002; Halliday, 1989; Koopman et al., 2003; Radford, 2009; Raja, 2016; Sa'adiyah Sy \& Reztia, 2019) have assessed the efficacy of using sentence structures in written forms with similar assertions as posited by Carter and McCarthy (1995; 2006) that sentence structures are essential in written and spoken. In an analysis of simple sentences, Demirezen (2012) found that due to poor proficiency, students misplaced the 
subject, verb, and object in a written sentence. In an investigation into complex sentences, Adaninggar (2017) discovered that $75 \%$ of teachers were unable to construct complex sentences in writing, but they could construct simple sentences by applying the $\mathrm{S}+\mathrm{V}+\mathrm{O}$ method correctly. Ika et al (2018) performed a similar study and found that $80 \%$ of the students were able to write complex sentences.

The above studies concur with the findings of Singh and Shamsudin (2009); Housen et al (2012), Kuiken and Vedder (2012), Lintunen and Makila (2014), and Tuan (2017) that competence in grammar should be equally emphasised in spoken and written forms.

In another study by Gillam and Johnston (1992); Zaharim et al (2010), it was discovered that proficiency and successful interaction in social contexts require the ability to utter multiple sentence structures to show meaningful interactions. As emphasised by Canale and Swain (1980; 1983); Barako and Schuele (2010); Dashti and Razmjoo (2020,) grammar rules apply to both speaking and writing. However, they further noted that less proficient speakers and writers were not able to express themselves correctly. Similarly, Fulcher (2003) asserted that both speaking and writing were creative abilities but speaking in a professional context should be comprehensively uttered as this denotes ones' proficiency.

In studies that set out to determine the proficiency of fresh graduates, Fan et al. (2017) reported that proficiency is one of the essential tools for getting jobs. In a follow-up study, Su-Hie et al (2019, p. 322-324) reported that "there were some candidates with broken and atrocious English, did not care about grammar" that interrupted interactions. In line with SuHie et al (2019); Zainuddin et al (2019) reported that fresh graduates who were unable to speak grammatically correct English failed to get jobs.

There were two studies conducted on the use of correct grammar in the IELTS speaking test by Roothooft and Breeze (2019); Dashti and Razmjoo (2020). They found that IELTS candidates were proficient and used complex structures compared to the candidates who lacked proficiency. These proficiently poor candidates were unable to use multiple sentence structures.

Collectively these studies support the notion that uttering multiple utterances in spoken language brings a significant impact in job interviews. Nevertheless, the current study attempts to fill the existing gap by obtaining a detailed understanding of the grammar in sentence structures un relation to competency (Canale \& Swain, 1980; 1983) by using Radford's (2009) framework of sentence structures to analyse the interactions between the interviewer and candidates.

\section{Method}

Consents were obtained from the organisation as well as the participants to conduct this study. The data were collected from one of the recruitment organisations that dealt with the hiring of staff. There were forty-five candidates who participated in the study and they were between 23 and 26 years. They did not speak English as their first language. They graduated from public universities with degrees in in social sciences and arts. Semistructured interviews were conducted with twenty-five hiring managers of different recruitment organisations. who were locals and from countries abroad. These hiring managers have more than 20 years of experience in conducting job interviews. The semi-structured interviews were conducted via Google meet as we were refrained from physical contacts due to the Covid-19 pandemic. Before conducting the semi-structured interviews, a brief explanation was given on the purpose of the study. The researcher was allowed to minimise and simplify the semi-structured interviews due to tight schedules during the ongoing 
pandemic. Additionally, the interview questions were adopted and modified based on the studies of Krishnan et al. (2017) and Zainuddin et al. (2019).

$\begin{array}{lll}\text { Successful } & \begin{array}{l}\text { IR: hai! I am XXX. Nice to see } \\ \text { you and ... please introduce } \\ \text { yourself. yes. }\end{array} & \begin{array}{l}\text { C3: good day to you Mr. I am XXX. This is } \\ \text { year graduated. I am XXX. I obtained my } \\ \text { bachelor degree from university of XXX. }\end{array} \\ \text { Reserved } & \begin{array}{l}\text { IR: could you introduce about } \\ \text { yourself (.) please }\end{array} & \begin{array}{l}\text { C22: well...my name is XXX. I am XXX years } \\ \text { old now...I have graduated from XXX (.) } \\ \text { Chemical Engineering }\end{array} \\ \text { Unsuccessful } & \begin{array}{l}\text { IR: can you introduce } \\ \text { yourself...please }\end{array} & \begin{array}{l}\text { (.) } 26: \text { my name is XXX...this year I am XXX } \\ \end{array}\end{array}$

The collected data were analysed qualitatively by utilising the NVIVO software. The data were transcribed and categorised based on Radford's (2009) definitions of sentence structures (see Table 2). The self-introduction question was chosen as a theme for the analysis as Hunting (2019) and Murchison (2017) noted that self-introduction is one of the important questions to commence job interviews. Li (2002), Wodak (2013) and Drisko (2019) noted that even an excerpt that is extracted from any written textual or spoken data can represent the analysis as a whole based on the objective of the study. Therefore, in the present study, only selected excerpts were used for the analysis. The interviewers are referred as IR (IR1, IR2, etc.), candidates as $\mathrm{C}(\mathrm{C} 1, \mathrm{C} 2$, etc.) and hiring managers as $\mathrm{HM}$ for the analysis purpose.

\section{Results and Discussion}

The analysis of sentence structure is based on the self-introduction theme. Table 2 shows the number of utterances (and its percentage) of successful, reserved and unsuccessful candidates.

\section{(Insert Table 2)}

Table 2 shows that the candidates uttered simple sentences rather than compound, complex and compound-complex sentences. Uttering simple sentences was not grammatically incorrect (Radford, 2009) but due to lack of proficiency, the candidates were unable to express their complete thoughts in one sentence. This may lead to a low chance of being hired. By employing multiple sentences, the candidates may display their English language proficiency. This finding concurs with Sa'adiyah Sy and Reztia (2019) that a complete thought represented in a sentence is essential in both spoken and written discourses.

The sample utterances by successful, reserved and unsuccessful candidates are shown below. The utterances are indicated in bold based on simple, compound, complex and compound-complex sentences.

\section{Extract 1-Simple Sentences}

C3 uttered 'good day...XXX' and C22 uttered 'well...engineering. Both uttered simple sentences to give the background information of themselves. If the information is constructed by uttering compound-complex sentences, it may give better impressions of themselves. On the contrary, C26 uttered a simple sentence, which is 'my ...I am XXX...' that consisted of name and age only but lacked personal information. In comparing C3 and C22 to C26, C3 and C22, 
the latter respondents are better. Nevertheless, due to C22's poor proficiency, the utterances were simple and the interviewer may expect further information. C26 on the other hand, was not able to provide more information.

This finding conforms Radford's (2009)view that uttering simple sentences is not wrong grammatically in a spoken context but if a speaker uses simple sentences, it shows limited proficiency. The finding is also consistent with the study conducted by Dimerize (2012) that poor proficiency makes students use simple sentences. The finding of the present study is also supported by the study of Housen et al. (2012) that a proficient speaker or writer expresses clearly in correct grammatical language. Halliday (1989) and Tuan (2017) also pointed that equal importance should be given to written and spoken sentence structures to portray ones proficiency.

Extract 2-Compound Sentences

\begin{tabular}{|c|c|c|}
\hline Successful & $\begin{array}{l}\text { IR: hi! I am XXX. Nice to see } \\
\text { you and ... please introduce } \\
\text { yourself... yes. }\end{array}$ & $\begin{array}{l}\text { C3: at the moment I continue my studies } \\
\text { and I have been looking for a job to } \\
\text { support myself. }\end{array}$ \\
\hline
\end{tabular}

Reserved IR: good...tell me C22: I have a friendly attitude when give something about yourself explanations to the customers

Unsuccessful IR: good Morning XXX. I am C23: well my name is XXX I am XXX happy if you could years old introduce yourself

C3 uttered compound sentences 'at the ... myself' to explain what C3 was doing and the reason for looking for a job. Similarly, C22 also used a compound sentence which is, 'I ...customers'. The sentence consists of two ideas that are equally important but did not elaborate details as compared to C3. C23 also uttered compound sentences 'well... old' which contained a bit of self-introduction information but seemed incomplete for the interviewer

The finding concurs with the study of Ika et al. (2018) that students have the tendency to use compound sentences. As Radford (2009) noted, sentence structures encompass spoken and written types of communication. Likewise, Chomsky $(1965 ; 2002)$ stated that grammar conventions should be used in spoken and not only in written forms. This is supported by the views of Candlin (2002) and Sarangi (2010) that in a professional context, spoken interaction is important to convey the intended meaning with complete thoughts to show one is proficient during job interviews. A combination of sentences would attract the attention of listeners and the communication would be appealing and effective. The use of simple sentences may be devoid of clear utterances, appear incoherent, and lack lucidity (Radford, 2009). 
Extract 3-Complex Sentences

Successful IR: say something about you... =yes about you (.) a little introduction about you

Reserved
IR: say something about you...=yes about you (.) a little introduction about you

Unsuccessful IR: So...tell me about you...

C3: after completing my bachelor and I decided to pursue my studies. I preferred to do psychology courses which would be very much useful for this Covid-19 pandemic where I can offer my services and counselling...

C17: then (.) I saw advertisement about your company that you need (.) consultants but I think I am suitable for the post which I applied for even though I do not have experience

C7: I am XXX... I am seek for a job...

C3 uttered 'after completing...counselling' which is a compound sentence that has an independent clause added to one or more dependent clauses. It is uttered to emphasise one idea after another. C3 wanted to emphasise that C3 had continued a master's programme 'after' the first degree. C17 uttered 'then...experience.' that consisted of a complete statement with a dependent word, such as 'then' and 'which'. Perhaps this sentence is the continuation of the self-introduction. However, C7 maintained the same utterances. In general, the words 'after', 'which', 'before' are used in complex sentences (Radford, 2009).

The finding of the study is supported by Adaninggar's (2017) study that less proficient speakers are unable to use complex sentences in either spoken or written forms. The finding is also supported by Halliday's (1989) view that complex sentences can be used in spoken and written forms if a speaker or a writer is proficient. Similarly, Scott and Windsor (2000) noted that the use of complex sentences portray ones' high proficiency either in on spoken or written communication.

Extract 4-Compound-complex Sentences

$\begin{array}{ll}\text { Successful } & \text { IR: hai! I am XXX Nice to see } \\ & \text { you and ... please introduce } \\ & \text { yourself... yes. }\end{array}$

Reserved IR: good...tell me something about yourself

Unsuccessful IR: okay...tell me about you...
C3: I can see many people affected with this pandemic and I would like to render my assistance by doing the masters which could be helpful in many ways.

C22: I have a very clear voice and can say fluently in English in two languages which are (.) Mandarin and Bahasa Melayu... C23...well...I am XXX... I am XXX years old.

C3 uttered 'I can....ways' that is a continuation of self-introduction and is a combination of compound-complex sentences. C22 also uttered compound-complex sentences 'I have a very... Bahasa Melayu'. However, C23 uttered 'well... old' but did not really answer questions related to self-introduction compared to $\mathrm{C} 3$ and $\mathrm{C} 22$.

The finding is consistent with the study of Housen et al. (2012) that a proficient speaker or writer is able to utter compound-complex sentences that depicts proficiency. 
Similarly, Zaharim et al. (2010) reported that with good proficiency, fresh graduates would be able to carry out meaningful interactions.

The present study also sought to establish the HMs' perceptions on the importance of English proficiency in the $21^{\text {st }}$ century workplace, especially the use of sentence structures in job interviews. Their responses are summarised as follows:

"English language proficiency is very much crucial in the $21^{\text {st }}$ century workplace. If you are unable to speak properly, I would say next and flip my pages and look for interesting essences".

"Some interviewers are apparently in favour of uttering what they refer to the simple sentence as it reflects more conventional usage, especially in job interview interactions. I don't particularly support that view. Generally, English language proficiency is one of the essential tools in job interviews. So, the use of more compound-complex sentences indicates a higher level of English proficiency in my opinion". Their responses concur with the studies of Fan et al. (2017) and Su-Hie et al. (2019) that proficiency is essential in job interviews which influences the obtaining of a job.

"A combination of simple and complex utterances in spoken interactions would seem normal to me in an interview situation. Whether utterances are effective or not would depend on many other issues, so I am not sure that the length or complexity of utterances is in itself so significant, but nothing beyond simple structures would seem a little unusual. In job interviews, I conduct, mainly with candidates for customer services we do expect candidates to provide full responses which would never be limited to simple utterances alone or in other word multiple sentences and can show meaningful conversions with good English language proficiency".

"Simple sentences contain one idea. Compound or complex sentences have two or more related answers in them. I am asking you if you interview someone who answers all simple sentences, how would you feel? One of the examples "I am Roy. I am 23 years old. I am a degree holder. I like to join this company. I can develop myself. I have computer skills". For me, lack of coherence and disjointed ideas are not promising at all. So, the use of compound-complex sentences is better in a professional context".

"Job interviews are professional conversations. I would anticipate that the candidates speak with good grammar in expressing comprehensive ideas/thoughts by uttering compound-complex sentences".

"I would prefer my candidates to speak professionally, e.g. good English by uttering mix sentences or complete thoughts so that I don't have to repeat the question again and again".

"It is good to bring this issue to higher learning institutions to revamp or enhance their existing course or training modules particularly on the language for employment, professional communication in job interviews to integrate the use of multiple sentence structures in a job interview, not only focusing on the sentence structures, other grammar components are essential too in job interviews. At the same time train the instructors who deliver language for employment courses and improve the teaching pedagogy according to $21^{\text {st }}$ century workplace readiness, especially communication skills".

It was found that the HMs have similar perceptions that English language proficiency plays an important role in the $21^{\text {st }}$ century workplace. Uttering multiple sentence structures 
in interviews may show one's proficiency in expressing complete thoughts and enables one to carry out meaningful interactions.

Their perceptions HMs on the use of sentence structures are supported by Radford (2009, p.234), Fan et al. (2017) and Su-Hie et al. (2019) that constructive sentence structures in spoken language especially in a professional interaction may have meaningful words like "words to the wise", as in job interviews. Further, the HMs noted that uttering disjointed ideas is not promising enough which is similar to the study of Hart et al. (2010). To conclude, these hiring managers agreed that the use of multiple sentences are essential in job interviews that portrays one's proficiency. Their perceptions correspond to Halliday (2014) that uttering multiple sentence structures are needed and applied based on the context, as in job interviews. The responses from HMs also agreed with the study of Alias et al. (2013) and Bhattacharyya $(2014 ; 2018)$ that interaction competence is also based on the context, as in job interviews that create favourable impression in the hiring process.

\section{Discussion}

The present study found that owing to poor proficiency, most of the candidates were unable to utter compound-complex sentences to talk about themselves. Utterances of simple, compound, complex and compound-complex sentences by candidates to provide background information for the self-introduction answers varied among the successful, reserved and unsuccessful candidates. The finding shows that most of the successful, reserved and unsuccessful candidates have used one single subject + verb that is considered a simple sentence, that can be seen in Table 3.

\section{(Insert Table 3)}

Uttering a combination of compound-complex sentences gives a better impression if these sentences are grammatically flawless as in a well-prepared opening statement and portrays one's proficiency in spoken or written form, as in job interviews (Radford, 2009; Fan et al., 2017). Radford and Fan et al.,'s (2017) views are supported by Halliday (2014, p.215) that the "use of various types of sentence structures could make an exceptional impression and portrays a speaker's proficiency". The self-introduction session signifies strong thoughts in constructing sensible responses by forestalling an interviewer's concerns in engaging a candidate.

Based on the questions asked by the interviewer on self-introduction, the candidates should have answered in a combination of compound-complex sentences. It gives greater insight by providing clear and well-prepared answers. One of the sample utterances of a successful candidate (C3) was selected with simple, compound, complex and compoundcomplex sentences for self-introduction is illustrated in Table 4.

\section{(Insert Table 4)}

The utterances from C3 were one of the favourable answers with a combination of compound-complex sentences as noted by Matthew and Nanette (2007); Hansen (2010), Hunting (2019) and Murchison (2017) that a self-introductionshould be covered in 30 seconds by a candidate by providing simple and relevant educational experiences, achievements and purpose for looking for a job.

In professional interactions, a combination of sentence structures creates significant value between speakers and listeners as noted by Hart et al (2010) as it encourages favourable utterances that are important in expressing complete thoughts in job interviews. 
This is because each utterance during job interviews carries value for the candidates. It displays a candidate's proficiency as can be seen in the differences between successful, reserved and unsuccessful candidates. Such a situation provides a chance for the candidates to be hired.

Radford (2009) asserted that longer utterances express comprehensive ideas and add more information to the interaction during job interviews. For example, the self-introduction question is simple and commonly asked during interviews but this is an essential question as noted by Murchison (2017); Hunting (2019). As this question is significant, the interviewer expects longer utterances as noted by Radford (2009) for this denotes one's proficiency during job interviews.

Pertaining to the HMs' perceptions, it was found that the HMs knew that English language proficiency playw a crucial role in job interviews. Furthermore, uttering multiple sentences could reveal a candidate's proficiency and indicatew the individual's ability to perform constructive interactions by expressing comprehensive thoughts. The HMs have also suggested revamping the existing training or course modules, particularly on the language for employment. Their perceptions are supported by Radford $(2009$, p.234) that productive sentence structures express thoughts wisely and meaningfully during job interviews.

The finding is also in line with the study of Bhattacharyya (2018) that stakeholders who are job seekers are equipped with the essential tools of the workplace. Further, HMs observed that expressing incoherent thoughts is not assuring and this is consistent with the studies by Alias et al (2013); Bhattacharyya (2014; 2018). They noted that communicative competence is also based on the context in which the interaction takes place during job interviews where proficiency in uttering correct sentences to express one's thoughts creates a favourable impact in the hiring process.

In conclusion, the perception of HMs has established that English language proficiency is very significant in the $21^{\text {st }}$ century workplace. Additionally, Halliday (2014) has observed that applying numerous sentence structures is needed to be employed.

In line with Halliday (2014), Tuan (2017) noted that a speaker or a writer should be good at grammar both in writing and speaking. As mentioned earlier, Radford (2009) noted that the use of a combination of sentence structures is not only used in good writing skills but it is also applied in speech to express one's thoughts. This may help in having meaningful interactions during job interviews. This is also supported by Carter and McCarthy $(1995 ; 2006)$ and Halliday (1989) that equal importance should be given to written and spoken forms. Hence, it is encouraged that English language proficiency, especially in uttering multiple types of sentences plays an important role during job interviews.

\section{Implications of the Study}

This finding has important implications for higher learning institutions as well as corporate sectors in Malaysia. The perceptions of HMs raise the need to revamp the language curriculum as well as proficiency courses or proficiency training modules for employment by reorganising the course modules. There should be greater focus devoted to equip students with good proficiency by integrating the use of grammar competence (Canale \& Swain 1980; 1983) especially sentence structures. All sentence structures should be based on the standard interview questions that will be asked during interviews. As Radford (2009) and Halliday (2014) have suggested, a combination of sentence structures is needed during job interviews.

Based on the National Graduate Employability Blue Print 2015-2025, it was reported that fresh graduates need good proficiency skills to drive a company's growth. There will be 
greater demand for fresh graduates who have strong proficiency and the ability to communicate well in job interviews (MHEM, 2016). In line with IR 4.0, there is a need to standardise English taught in schools and higher learning institutions, and a standard should be set to enable learners to interact in English (Council of Europe, 2016). As far as English language education is concerned, the Common European Framework of Reference for Languages (CEFR) should be complied from pre-school to tertiary education. Thus, Malaysians graduates who complete their formal education will have the necessary skills to meet the demands of job market.

This study would also create greater awareness among undergraduates/ fresh graduates that academic qualifications alone will not lead to success in job interviews. The ability to communicate effectively by uttering sentence structures that are grammatically correct and precise to show proficiency and is important in job interviews (Truman, 2011).

\section{Conclusion}

In conclusion, this study has shown most of the successful, reserved and unsuccessful candidates used simple sentences that have one single subject + verb. The candidates were not able to utter compound-complex sentences to express their complete thoughts. Uttering simple sentences is not wrong grammatically but is an indication of the poor proficiency of the speaker (Radford, 2009). Uttering a combination of compound-complex sentences gives better awareness of grammar as long as they are flawless especially in an opening statement.

This study is only limited to a few sentence structures especially during job interviews and did not investigate non-verbal communication and pronunciation. However, the findings of the present study provide insights for further research that should explore speech functions; complex clauses that go along with non-verbal communication and pronunciation during job interviews.

\section{References}

Abu Bakar, A. (2020). English barrier for Bumiputera graduates in job hunt. https://www.freemalaysiatoday.com/category/nation/2020/09/20/english-barrierfor-bumiputera-graduates-in-job-hunt-says-mef/

Adaninggar, S. S. (2017). A study of the mastery of complex sentences of pre-service English teachers in writing. Ahmad Dahlan Journal of English Studies, 4 (2), 21-26. https://www.researchgate.net/publication/322794893

Ahmed, S. T. (2018). Communicative competence in English as a foreign language: Its meaning and the pedagogical considerations for its development. GRIN Verlag. https://www.grin.com/document/432042

Alias, M., Sidhu, G. K., \& Chan, Y. F. (2013). Unemployed graduates' perceptions on their general communication skills at job interviews. Elsevier Procedia-Social and Behavioral Sciences,90(1), 324-333. https://www.researchgate.net/publication/273853269

Bachman, L. F., \& Palmer, A. S. (1996). Language testing in practice. Oxford University Press

Bachman, L. F., \& Palmer, A. S. (2010). Language assessment practice: Developing language assessments and justifying their use in the real world. Oxford University Press.

Bhattacharyya, E. (2014). A case study of stakeholder perceptions on communicative competence in engineering technical oral presentation (Doctoral dissertation, University Malaya). https:// UM Students' Repository 
Bhattacharyya, E. (2018). Stakeholders perspective on communicative competence in industry 4.0: Walk the talk of informative technologists. SHS Web of Conferences 53(1), 1-12. https://Stakeholders Perspective on Communicative Competence in Industry 4.0

Barako, A. K., \& Schuele, C. M. (2010). A framework for analyzing complex syntax in language samples. Seminar presented at the Annual Convention of the American SpeechLanguage-Hearing Association, Philadelphia, PA https://www.researchgate.net/publication/334896605

Canale, M., \& Swain, M. (1980). Theoretical bases of communicative approaches to second language teaching and testing. Applied Linguistics, 1(1), 1-47. https://doi.org/10.1093/applin/l.1.1

Canale, M. (1983). From communicative competence to communicative language pedagogy. In J. C. Richards \& R. W. Schmidt (Eds.). Language and communication (pp. 2-27). Longman.

Canale, M. (1984). A communicative approach to language proficiency assessment in a minority

setting. In C. Rivera (Ed.), Communicative competence approaches to language proficiency assessment: Research and application (pp.107-122). Clevedon: Multilingual Matters.

Carter, R., \& McCarthy, M. J. (1995). Grammar and the spoken language, Applied Linguistics, 16 (2),141-58. https://OP-APPL140081 1.21 (semanticscholar.org)

Carter, R., \& McCarthy, M. J. (2006). Cambridge Grammar of English: A Comprehensive Guide. Spoken and Written English Grammar and Usage. Cambridge University Press

Catherine, W. (1997). How English works: A grammar practice book. Oxford: OUP. ISBN 978-0194314565.

Chomsky, N. (1957). Syntactic structures. Mouton

Chomsky, N. (1965). Aspects of the Theory of Syntax. Cambridge, Massachusetts: The M.I.T. Press.

Chomsky, N. (2002). Syntactic Structures. Berlin: Mouton de Gruyter.

Christina, C. (2018). Varsity aims to boost grads' employability. The Star. https://www.thestar.com.my/news/nation/2018/03/04/varsity-aims-to-boost-gradsemployability/

Cleland, A. A., \& Pickering, M. J. (2006), Do writing and speaking employ the same syntactic representations? Journal of Memory and Language, 54(2), 185-198. https://abdn.pure.elsevier.com/en/publications/do-writing-and-speaking-employ-thesame-syntactic-representations

Council of Europe. (2016). Common European Framework of Reference for Languages: Learning, Teaching, Assessment (CEFR). https://www.coe.int/en/web/commoneuropean-framework-reference-languages

Candlin, C. N. (2002). Research and Practice in Professional Discourse. (Ed.) Hong Kong: City

Dashti, L., \& Razmjoo, S. A. (2020) An examination of IELTS candidates' performances at different band scores of the speaking test: $A$ quantitative and qualitative analysis, Cogent Education, 7(1),1-27. https://doi.org/10.1080/2331186X.2020.1770936

Demirezen, P. (2012). An analysis of the problem-causing structures of simple sentences for Turkish University Students. International Journal of Humanities and Social Science, 2 (3),136-146. http://www.ijhssnet.com/journals/ 
Drisko, J. W. (2019). Qualitative research synthesis: An appreciative and critical introduction. Qualitative Social Work, $0(0), 1-18$. https://doi.org/10.1177/1473325019848808

Fan, L., Feia, J., Schrievera, U., Fan, S. (2017). The communicative competence of Chinese seafarers and their employability in the international maritime labour market, Elsevier, 83(1), 137-145. https://doi.org/10.1016/j.marpol.2017.05.035

Fulcher, G. (2003). Testing second language speaking. Longman/Pearson Education

Gillam, R., \& Johnston, J. (1992). Spoken and written language relationships in language/learning-impaired and normally achieving school-age children. Journal of Speech and Hearing Research, 1 (35), 1303-1315. https://www.researchgate.net/publication/21871316

Halliday, M. A. K. (1989). Spoken and written language. Oxford University Press.

Halliday, M. A. K. (2014). An introduction to functional grammar. London:

Hart, D., Grigal, M., \& Weir, C. (2010). Promising utterances: A snapshot of postsecondary education for students with intellectual disabilities across the United States, Think

College Fast Facts, 1 (2), 4-17. https://eric.ed.gov/?id=EJ966123

Hansen, K. (2010), What do employers really want? Top skills and values employers seek from job-seekers. Quintessential careers [Msg 12]. http://www.quintcareers.com/job_skills_values.html

Hedge, T. (2000). Teaching and learning in the language classroom. Oxford: Oxford University Press.

Housen, A., \& Kuiken, F. (2009). Complexity, accuracy and fluency in second language acquisition. Applied Linguistics, 30 (4), 461-473. https://www.researchgate.net/publication/265887417

Huddleston, R. (1984). Introduction to the grammar of English. Cambridge University Press. ISBN 978-0-521-29704-2.

Hunting, J. (2019). Job Interview: This book includes: guide to a winning interview, how to answer questions, preparation, questions and answers. (Kindle Edition). Dallas, Texas.

Hymes, D. (1972). On communicative competence. In J. B. Pride \& J. Holmes (Eds.), Sociolinguistics: Selected Readings (pp. 269). Baltimore: Penguin.

Ika, D. S., Hermawati, S., \& Zul, A. (2018). An analysis of compound sentences in students' writing, Advances in Social Science, Education and Humanities Research, 30 (1),341348. https://doi.org/10.2991/icla-18.2019.57

Lintunen, P., \& Makila, M. (2014). Measuring syntactic complexity in spoken and written learner language: comparing the incomparable? Research in Language, 12, (4), 377-399. https://www.researchgate.net/publication/286841734

Kagermann, H., Wahlster,W. \& Helbig, J. (2013). Recommendations for implementing the strategic initiative industry 4.0 (Eds.), Final report of the industry 4.0 Working Group.

Koopman, H., Sportiche, D., \& Stabler, E. (2003), An Introduction to Syntactic Analysis and Theory. Unpublished Manuscript, (April), 246. http://citeseerx.ist.psu.edu/viewdoc/download?doi=10.1.1.122.5914

Krishnan, I. A., Ramalingam, S. J., Hee, S. C., \& Maruthan, E. (2017). The selection practices and recruitments of fresh graduates in local organisation's job interview. Journal of Language and Communication, 4(2), 153-116. https://www.academia.edu/36569540/

Li, W. (2002). What do you want me to say?' On the conversation. Language in Society, 3 (3), 
159-180. https://www.researchgate.net/publication/231965264

Matthew, J. D., \& Nanette., D. (2007), Perfect phrases for negotiating salary and job offers. ISBN 978-981-4646-75-8. McGraw Hill Education.

MHEM. (2016). The national graduate employability blue print 2015-2025. Ministry of Higher Education Malaysia, Putra Jaya Malaysia, ISBN:978-967-0444-43-2.65.

Morreale, S. P., Spitzberg, B. H., Barge, J. K. (2007). Human communication: Motivation, knowledge, and skills. 2nd ed. Belmont, CA: Thomson \& Wadsworth.

Murchison, H. M. (2017), Tell Me About Yourself: Six Steps for Accurate and Artful SelfDefinition. Berrett-Koehler Publishers; (1 ${ }^{\text {st }}$ edition). Oakland USA. ISBN-13: 9781523094660

Ohno, A. (2011). Communicative competence and communicative language teaching. http://cicero.u-bunkyo.ac.jp/lib/kiyo/fsell2002/25-32

Pandey, M., \& Pandey, P. (2014). Better English for better employment opportunities. International Journal of Multidisciplinary Approach and Studies, 1 (4), 93-100. https://www.researchgate.net/publication/264788119

Peck, B. S. (2018). Industry 4.0 success depends on key factors. https://www.thestar.com.my/news/nation/2018/01/24/industry-40-success-dependson- key-factors/ https://www.researchgate.net/publication/264788119

Radford, A. (1988). Transformational grammar. Cambridge, UK: Cambridge University Press Radford, A. (1990). Transformational Grammar. Cambridge: Cambridge University Press. Radford, A. (1997). Syntactic theory and the structure of English: A Minimalist approach (Cambridge Textbooks in Linguistics). Cambridge, UK: Cambridge University Press

Radford, A. (2009). An introduction to English sentence structure. (Grammar and Syntax, Language and Linguistics) Cambridge, UK: Cambridge University Press. 1-445.https://doi.org/10.1017/СВ09780511800924

Raja, S. G. (2016). English syntax: the analysis of sentence structure, An International Multidisciplinary Research Journal, 6 (9), 163-176. http://dx.doi.org/10.5958/22497137.2016.00062.8

Roothooft, H., \& Breeze, R. (2019). Investigating the development of 'grammatical range and accuracy' at different proficiency levels in the IELTS Speaking test. IELTS Research Reports Online Series 1, ISSN 2201-2982. https://www.semanticscholar.org/

Sy, S. E. N., \& Reztia, A. D (2019). A syntactical analysis of simple sentences in Kembhang Babur, Journal of English Education and Applied Linguistics, 8 (2), 163-175. https://www.researchgate.net/publication/336907322

Sarangi, S. (2010). Motivational relevancies: some methodological reflections on sociolinguistic practice. In Sociolinguistics and Social Theory 350-388. London: Pearson. (pp.17 \& 30). London, England: Spiringer-Verlag.

Scott, C., \& Windsor, J. (2000). General language performance measures in spoken and written narrative and expository discourse of school-age children with language learning disabilities. Journal of Speech, Language, and Hearing Research, 4 (3), 324-339. https://pubmed.ncbi.nlm.nih.gov/10757687/

Singh, M. K. S. \& Shamsudin, S. (2009). Arriving at the interface of pragmatic and grammatical competence. Conference Paper. http://www.researchgate.net/publication/257173188

Singh, R. (2018). Language main barrier to grads getting jobs. The Sun Daily. http://www.thesundaily.my/news/2018/01/22/language-main-barrier-grads-gettingjobsupdated 
Su-Hie, T., Marzuki, E., Kee-Man, C., Jecky, M., \& Collin, J. (2017). Employers' views on the importance of English proficiency and communication skill for employability in Malaysia, Indonesian Journal of Applied Linguistics, 7, (2), 315-327. http:// 10.17509/ijal.v7i2.8132

Swan, M. (2005). Grammar (Oxford Introduction to Language Study ELT). Oxford: OUP. ISBN 978-0194372411.

Truman, H. S. (2011), Management study of communication skills. Journal of Human Resource, 1, (1), 11-32. https://www.researchgate.net/publication/334273305

Tuan, V. V. (2017), Communicative Competence of the Fourth Year Students: Basis for Proposed English Language Program. English Language Teaching, 10, (7), 104-122. http://doi.org/10.5539/elt.v10n7p104

Ujang, A. (2019). Malaysians struggling with English. The Sun Daily. https://www.thesundaily.my/opinion/malaysians-struggling-with-english-FC433412

Wiemann, J. M. (1977), Explication and test of a model of communication competence. Human Communication Research,3 (2),195-213.

Wodak, R. (2013). Critical discourse analysis. London, UK; Sage.

Zainuddin, S. Z., Pillai, S., Dumanig, F. P., \&Phillip, A. (2019). English language and graduate employability, Education + Training, 61(1), 79-93. https://doi.org/10.1108/ET06-2017-0089

Zaharim, A., Omar, M. Z., Yusoff, Y. M., Muhamad, N., Mohamed, A., \& Mustapha, R. (2010). Practical framework of employability skills for engineering graduate in Malaysia. IEEE EDUCON Conference. http://ieeexplore.ieee.org/ document/5492478. 


\section{Table 1}

\section{Definition of Sentence Structures}

\begin{tabular}{|c|c|}
\hline Sentence Structures & Definitions and Sample Sentences \\
\hline 1.Simple Sentence & $\begin{array}{l}\text { A simple sentence refers to a sentence consisting of a } \\
\text { combination of S+V (Subject +Verb), which is the compulsory } \\
\text { structure. Simple sentence can be constructed in a few ways, } \\
\text { as below: } \\
\text { a. S + V } \\
\text { e.g. He cried. } \\
\text { Subject- He } \\
\text { Verb- cried } \\
\text { b. S + V + C (Complement) } \\
\text { e.g. He is happy. } \\
\text { Subject- He } \\
\text { Verb -is happy } \\
\text { Complement- happy } \\
\text { Complement functions to complete the sentence. Otherwise, } \\
\text { the sentence will be ungrammatically correct as "He is."- not } \\
\text { correct and hanging. Thus, a Complement is to complete. } \\
\text { c. S + V + O } \\
\text { e.g. He ate an apple } \\
\text { Subject- He } \\
\text { Verb- ate } \\
\text { Object- an apple } \\
\text { The verb in the above example is a transitive verb, which } \\
\text { requires an Object. An Object can be either a noun/noun } \\
\text { phrase or a pronoun. } \\
\text { e.g. } \\
\text { He is happy. }\end{array}$ \\
\hline 2. Compound & $\begin{array}{l}\text { A compound sentence refers to two simple sentences } \\
\text { connected by conjunctions like and, but, or, yet, for, nor, so or } \\
\text { linking words or coordinators such as; as a result, thus, } \\
\text { therefore, however, in addition, moreover. } \\
\text { e.g. } \\
\text { He is happy but his mother is always complaining. }\end{array}$ \\
\hline
\end{tabular}




\begin{tabular}{|c|c|}
\hline & $\begin{array}{l}\text { Conjunction/ linking words-but } \\
\text { Independent clause-is happy and his mother is always } \\
\text { complaining }\end{array}$ \\
\hline 3.Complex & $\begin{array}{l}\text { A complex sentence refers to one independent added with } \\
\text { one or more dependent clauses. } \\
\text { e.g. } \\
\text { John is happy even though he does not make much money. } \\
\text { Dependent clause- even though he does not make much } \\
\text { money }\end{array}$ \\
\hline 4.Compound-Complex & $\begin{array}{l}\text { A compound and complex sentence refers to two } \\
\text { independent added with one dependent clause. } \\
\text { e.g. } \\
\text { He is happy, even though he does not make much money, } \\
\text { but his mother is always complaining since they do not have } \\
\text { enough money to buy the new car. } \\
\text { Independent clause-'He is happy' and 'his mother is always } \\
\text { complaining } \\
\text { Dependent clause-'Even though he does not make much } \\
\text { Money' and 'since they do not have enough } \\
\text { money to but the new car'. } \\
\text { Linking words-but }\end{array}$ \\
\hline
\end{tabular}

Source: Types of Sentence Structures (Radford, 2009)

Table 2

Number of Utterances of Sentence Structures of Successful, Reserved and Unsuccessful Candidates

\begin{tabular}{l|c|c|c|c|c}
\hline Candidates & $\begin{array}{c}\text { Total } \\
\text { Sentences }\end{array}$ & $\begin{array}{c}\text { Number of } \\
\text { utterances } \\
\text { of Simple } \\
\text { Sentences }\end{array}$ & $\begin{array}{c}\text { Number of } \\
\text { utterances } \\
\text { Compound } \\
\text { Sentences }\end{array}$ & $\begin{array}{c}\text { Number of } \\
\text { utterances } \\
\text { Complex } \\
\text { Sentences }\end{array}$ & $\begin{array}{c}\text { Number of } \\
\text { utterances } \\
\text { Compound- } \\
\text { Complex } \\
\text { Sentences }\end{array}$ \\
\hline $\begin{array}{l}\text { Successful } \\
\text { Reserved }\end{array}$ & 198 & $62.6 \%$ & $15.2 \%$ & $18.2 \%$ & $4 \%$ \\
Unsuccessful & 127 & $72.4 \%$ & $16.5 \%$ & $6.3 \%$ & $4.72 \%$ \\
\hline
\end{tabular}




\title{
Table 3
}

Utterances of Simple Sentence of Successful, Reserved and Unsuccessful Candidates of Selfintroduction

\author{
e.g. Successful: C3: Good day to you Mr. I (s) am (V) XXX. This is year \\ I (S)am (V) XXX. I (S)obtained (V) my bachelor degree from \\ University of XXX.
}

Reserved: $\quad$ C22: well...my (S) name is XXX. I am XXX years old now I have graduated from UiTM (.) chemical Engineering.

Unsuccessful: C 22: my name (S) is $(V)$ XXX ...this year I (S) am (V) $\mathrm{XXX}($.

\section{Table 4}

The Combination of Sample Utterances of Compound-complex Sentence of Successful Candidate on the Self-introduction

\section{C3:}

Good day to you Mr. I (S) am (V) XXX and (Conj) this is year I (S) am (V) XXX. I (S) obtained (V) my bachelor degree from University of XXX. At the moment I continue my studies and (Conj) I have been looking for a job to support myself (Dependent Clause- Independent as it is connected by a Conj). After completing my (S) bachelor and (Conj) I (S) decided to pursue my (S) studies which (Dependent Clause) I (S) preferred to do psychology courses which (Dependent Clause) would be very much useful for this Covid-19 pandemic where I (S) can offer my services and counselling. I (S) can see many people affected with this pandemic and (independent clause) I would like to render my assistance by doing the masters which could be helpful in many ways. 